\title{
Ergology and socio-ideological view of communication: toward a base to rethink the organization's constitution
}

\author{
Gislene Feiten Haubrich*
}

Ernani Cesar de Freitas**

\section{Abstract}

Mundialization and technological development are vectors pushing changes in humankind's patterns of interaction. Then, they also imply people's perception and engagement in reality building around them. The organizational context is deeply involved by these processes, what is highlighted, for example, by workers endeavors as the creation of shared, collaborative and non-hierarchical environments of work. These features support our research question: how could we understand organizations by a communicative constitution point of view? The argument that guides us to find answers for it is based on interconnection between ergological and socio-ideological perspectives and it finds the field in the coworking concept debate. The article is divided into four parts, starting with the interrelation between notions of work's activity and verbal interaction, as a means to understand the communicative process that constitutes organizations. Finally, the coworking concept constitutes the horizon to justify our proposal.

Keywords: Ergology. Socio-ideological perspective. CCO. Coworking.

* Doutora e Mestre em Processos e Manifestações Culturais na Universidade Feevale. Realizou estudos na modalidade doutorado sanduíche na Université de Strasbourg (LISEC - Ergologie). Especialista em Comunicação Estratégica e Branding pela UMayor (Chile) e Universidade Feevale. Graduada em Comunicação Social, habilitação em Relações Públicas pela Universidade Feevale. E-mail: isleneh@gmail.com

** Pós-doutorado em Linguística Aplicada e Estudos da Linguagem - PUC-SP/LAEL (2011); Doutor em Letras, área de concentração Lingüística Aplicada (PUCRS/2006); Mestre em Linguística Aplicada pela Universidade do Vale do Rio dos Sinos (Unisinos/2002). Possui graduação em Letras - Português/Inglês e respectivas Literaturas, pelo Centro Universitario La Salle (1999). Professor (Titular) de Ensino Superior na Universidade Feevale, Programa de Pós-graduação em Processos e Manifestações Culturais, e professor permanente no PPG em Letras na Universidade de Passo Fundo (RS). Integrante de conselhos editorias e parecerista ad hoc de revistas acadêmicas. Membro da Associação de Linguística Aplicada do Brasil (ALAB), da Associação Brasileira de Linguística (ABRALIN); da Asociación Latinoamericana de Estudios del Discurso (ALED); da Asociación de Lingüística y Filología de América Latina (ALFAL); da Association Analyse des Discours de l'Amérique Latine (ADAL/Paris); coordenador (2018-2020) e participante efetivo do GT ANPOLL- Linguagem, Enunciação e Trabalho. ORCID iD: https://orcid.org/0000-0002-8920-9446. E-mail: nanicesar@terra.com.br

Data de submissão: ago. 2019 - Data de aceite: out. 2019 http://dx.doi.org/10.5335/rdes.v15i3.9631 


\section{Introduction}

The technological increase is a fact. Devices of the most varied types emerge minute by minute. The presence of machines in everyday life intensifies and transforms relationships between individuals and technologies. Nevertheless, the connection that a person has with itself and with others around him/her is also modified. In the wake of these changes, the way we understand what work means also has to modify, highlighting it as a human activity that guarantees the constitution of the main part of our social web. Consequently, the perception about what is an organization will be transformed, once that people's connections are result of the way they see and live the world around them. Despite this intensive picture of change itself, in our point of view, the main problem is the look invested on work, that's usually tied to the bonds of the standardized production system and far away from human's activity regarding.

To reach our discussion on this text, we believe that the reader should have in mind some presumptions that guided us to dig in. The first concerns the way we understand the culture. Considering Cuche (1999) and Geertz (2008) ideas, we can assume it as a process, never concluded, but always related to people's behavior. The second supposition is based on the notion of work as a human activity, grounded in time and space; therefore unique. To conclude this short overview, we defend a large comprehension of communication, emphasizing the different types of interactions that a person experiences in daily life with people and/or resources. The connection between these assumptions supports our argument to rethink what is an organization and how it affects our relationship with reality.

These ideas demonstrate our effort to understand organizations from a different outlook, which emphasizes the role of people in the constitution of the social reality. This exchange is like a key to recognize the coworking phenomenon beyond a space physically described, but as an organization, communicatively constituted. Results from our latest research (HAUBRICH, 2019) demonstrate that just a few studies are devoted to interpret coworking from labor aspects interrelated to organization's understanding. Besides, we consider the frequent remark related to coworking as "a new way of work". But how do they deliver this? In this direction, reports from McKinsey Global Institute (2017) and Deloitte Insights (2019) invite us to think about the future of work. Considering the importance that work still has in our societies, we believe that a strong connection between human activity, interactions, and organizations 
is a guide to search answers for some of the questions that surround this subject.

In this context, we assume that an organization shall be understood as a complex web of discourses, produced by many actors at work. We argue that the movement between the prescribed rules and the renormalizations is the base to view organizations as communicatively constituted. The article aims to provide a dialogue between ideas of Ergology and Bakhtin's Circle, instigating different readings for the organizational constitution. This shift of mindset means that we are putting our focus on the process of people's creation when they interact, instead of the result of some imposition that comes from a superior or owner, for example. To support these assumptions, we'll produce a dialogue among the premises of Communicative Constitution of Organization (CCO) (COOREN, et al., 2011), the concept of human activity of work, from Ergology (SCHWARTZ; DURRIVE, 2003, 2009), and the socio-ideological perspective of language, from Bakhtin's Circle (BAKHTIN, 2010, 2016; VOLÓCHINOV, 2017).

Considering these points, the scenario of coworking was selected for both reasons, to apply the proposal and to rethink its concept, considering it as an organization based on interactions, then, communicatively constituted. We argue that this change of perspective, it's like an open gate to move into worker's experience. We also defend that a connection between individual realities and collective organization may be perceived by a sort of discourses. Once they reveal clues about context and values around it, we can identify cultural aspects in a direction that considers different communicative levels. The emphasis of our research is people's work, especially seeing that they chose to be in a shared environment to do their job. From the dialogue that we are proposing, the workers are also invited to dig deep into themselves, looking for interpretations on specific situations.

In our point of view, these aspects may be a fundamental tool for each coworker to evaluate their own choices in daily life. Besides, the discursive support for our interpretation helps us to understand what moves work in coworking and why people choose to be in there, searching by answers in the micro situations at work. Several aspects of work in coworking spaces are gaining attention of researchers around the globe (VIDAILLET; BOUSALHAM, 2018; BLAGOEV; COSTAS; KÄRREMAN, 2019). But with our research, we are especially concerned about the large concept proposed by Jones et al. (2009) that defines coworking based on three points: 1) as an activity that implies work collectively and collaboratively; 2) as a space, where people pay to be and chose 
work in, and 3) a movement, which aims to transform the way people work. Thus, the main contribution of this research is to provide a different perspective on how people are connected by their work, which means consider a different ground to define what organizations are.

We believe that the only way to provide this change is rethinking what work means, especially in a context where people are asked to producing knowledge, being creative and entrepreneur. So, when we look at the coworking phenomenon, we devote our regard to people's interactions, based on the idea that their decisions and renormalizations play a very important role in the culture of the organization to the point to constitute them. This text is divided into three parts. The first one is devoted to present CCO's perspective and defines what we mean by organization. In the second part, we present the main concepts from ergology and socio-ideological view of language. In the last part of this article, we perform an analysis of the term coworking based on some definitions and the main dialogue introduced in the previous sections.

\section{What do we mean by an organization?}

Alterity. Comprehend what it means isn't an easy task. It demands from the individuals the acceptance that we are interconnected between each other and that we are working together to build the world. Studies developed by Deetz (2010) and Wolton (2011) show us how important alterity is to think about communicative process, as well them proposed by Bakhtin (2010, 2015), Volóchinov (2017) and Schwartz \& Durrive (2003, 2009). Considering both, communication and alterity, we may ask ourselves: what is an organization after all? An interesting point of view is being presented by Putnam, Nicotera \& Mcphee (2009, p. 9), for whom "communication and organization are not equivalent concepts per se, but they are mutually constitutive". To summarize these ideas, we comprehend that an organization is built based on communicative processes, what means consider people's intervention to establish different connections. However, how this modify our understanding about work and society?

According to McPhee \& Zaug (2009), the Communicative Constitution of Organizations (CCO) theory recognizes communication as a constitutive force, which means to consider the social actors interacting collectively, thus establishing a set of cultural processes. McPhee and Zaug (2009) were the first authors to use the term CCO when studying organizations. Their perspective is based on the flows of circulation systems or message fields. However, these interactional flows go far beyond the transmission of 
information "[...] but become conditions mediated in later interaction episodes involving the initial parties or others". (McPHEE; ZAUG, 2009, p. 29). Since McPhee and Zaug's proposition, several authors have been contributing with this perspective, as we can mention the three preeminent schools: 1) The Four Flows Model (McPHEE, 2009); 2) The Montreal School (TAYLOR, 2000), and 3) Luhmann's Social Systems (SCHOENEBORN, 2011).

Despite the differences among the understandings, Cooren et al. (2011) identified six premises and defined them as a guide for organizational readings that may arise based on CCO. In the Table 1, we synthetize the main ideas coming from these premises.

Table 1 - The six premises of COO

\begin{tabular}{|c|c|c|}
\hline & Premise & Main ideas \\
\hline 1 & $\begin{array}{l}\text { CCO scholarship studies communicational } \\
\text { events }\end{array}$ & $\begin{array}{l}{[\ldots] \text { any turn of talk, discourse, artifact, metaphor, }} \\
\text { architectural element, body, text or narrative should at } \\
\text { least be considered in its performative or transactional } \\
\text { dimension". [...] "a segment of an ongoing and situated } \\
\text { stream of socio-discursive practice". }\end{array}$ \\
\hline 2 & $\begin{array}{l}\text { CCO scholarship should be as inclusive } \\
\text { as possible about what we mean by } \\
\text { (organizational) communication }\end{array}$ & $\begin{array}{l}\text { Textual (documents, conversation, formal talks) ; } \\
\text { Clothes, gestures, behaves. }\end{array}$ \\
\hline 3 & $\begin{array}{l}\text { CCO scholarship acknowledges the co- } \\
\text { constructed or co-oriented nature of } \\
\text { (organizational) communication. }\end{array}$ & $\begin{array}{l}\text { "[...] any performance will never be reducible to the way it } \\
\text { was intended or meant by its producer". }\end{array}$ \\
\hline 4 & $\begin{array}{l}\text { CCO scholarship holds that who or what is } \\
\text { acting always is an open question }\end{array}$ & $\begin{array}{l}\text { "we not only focus on human agency, but also on other } \\
\text { forms of agency (textual, architectural, artifactual, } \\
\text { technological, etc.)". }\end{array}$ \\
\hline 5 & $\begin{array}{l}\text { CCO scholarship never leaves the realm of } \\
\text { communicational events }\end{array}$ & Identify communicational events as a unit of analysis. \\
\hline 6 & $\begin{array}{l}\text { CCO scholarship favors neither organizing } \\
\text { nor organization. }\end{array}$ & $\begin{array}{l}\text { "CCO scholarship refuses to choose between studying } \\
\text { how people get organized and how organizations come } \\
\text { to be reenacted and reproduced through these activities". }\end{array}$ \\
\hline
\end{tabular}

Source: elaborated by the authors based on Cooren et al. (2011, p. 1151 - 1153).

Table 1 summarizes the ideas proposed by Cooren et al. (2011) considering the premises that researchers should follow to contribute with CCO. As we can assume based on this table, the purpose is stretching the comprehension over the communicative phenomenon, which means, looking to people and their creations together. We'll retake these premises in the last section of this article when we connect all the theoretical approaches to examine the notion of coworking as organization (entity), organizing (process), and 
organizationality. About this last concept, we chose to aggregate it since of the work from Dobusch \& Schoeneborn (2015) and Schoeneborn, Kuhn, \& Kärreman (2018). "We define organizationality as the degree to which a social collective displays three characteristics of organization: (1) interconnected instances of decisionmaking, (2) actorhood, and (3) identity". (DOBUSCH; SCHOENEBORN, 2015, p. 1008). Once we have defined what we mean by organization and how it's related to communication, we can advance to our core understanding about work.

\section{If we have a different background, maybe we could have other view}

Once the CCO is a perspective built by many hands, we attempt to contribute with it providing different bricks. We may justify this choice considering the work as the main base of an organization since all interactions arise based on cultural predefinitions and events from everyday life. Taking these points, we come up with the dialogue between Ergology and Socio-ideologic approaches. Since this is a new perspective to the domain of communication in organizational context, this section is devoted to describe the main ideas of each one to connect them at the last section. Starting by Ergology, it refers to a multidisciplinary perspective to analyze and understand the activity of work. Durrive (2015, p. 42) affirms that "a human activity spontaneously structures itself within the limits of its existence". In other words, the action taken by the self-body ${ }^{1}$ (corps-soi) organizes the environment around him/herself, and the limits defined by the possibilities of manipulation in the situation.

Ergology is rooted in three main theories. The first, Ergonomic Work Analysis (EWA), headed by Alain Wisner, supports the fact that exists a gap between the prescribed to the workers and the performed by them. Clinical Activity's contribution comes especially from the methodology "instruction to a double", proposed by Ivar Oddone, and supports the comprehension of savoirs ${ }^{2}$. Finally, Canguilhem's philosophy endorses the understanding of three points: 1) the prescribed can be materialized by norms in different levels, 2) the real manifests itself in renormalizations, and 3) the gaps (prescribed and experienced) imply the dramatic uses of self-body. (HAUBRICH, 2019). Based on these core perspectives we have a bright picture about the notion of activity as a process that combines the adherent (situation here and now - hic et nunc) and the nonadherent (norms, prescriptions, predefinitions).

The self-body receives a range of norms from several directions: family, school, university, professional forma- 
tion, organization, and society. However, according to Schwartz \& Durrive (2003, 2009), these guides are not enough to define how life happens, specially at work. As workers, we may have a schedule to follow, but usually, it isn't faithful pursued, because the context is performed by people, who interpret the norms differently and perform the activity from that interpretation. The path from the prescribed to the performed defines the activity and results in renormalizations, creation of saviors, remodeling standards of behavior and culture. How may we understand this path? In line with the dramatics of self-body use. Schwartz (1998, p. 7) asserts that "all work activity is always a 'dramatic of self-body use', a problem of negotiation [...] the substance, the content, the circumstances of these dramatics, the way they weave heterogeneous elements [...] 'make history' more or less locally or globally".

Every norm comes from the 'other', the alterity, that can be a person, an organization, and/or a community. Connected with cultural standards, and we always do, we are experiencing the 'self-body use by the other's. As species, we are all connected, and we are constantly receiving patterns and guides to our evaluation over both, social and personal situations. The decision process in the situation is orientated by the interpretation of the norms, what means that we are choosing from our criteria and interests face to the context. The self-choice is 'self-body use by him/herself". For each norm that we receive, we have multiple choices to decide how to follow it. Maybe the reason that supports a choice comes from some pressure to avoid problems with hierarchy, for example. Perhaps other answers justify what we privilege in each specific situation. The point is: we choose, we renormalize from this interpretation and performance. We'll increase this perspective following this section.

The background provided by Ergology helps us to endure that the concept of work is very complex, which crosses all levels of an organization. It goes beyond the results, progressing by a process that interferes intensely at workers' life and perception of the surrounding. As a human activity, work situations are unrepeatable and unpredictable. Here, the focus is on workers' choices and also in the institutional definitions, both in permanent fusion. These crossing perspectives imply several changes in our understanding of the organization constitution because it rises by perceptions, meanings, and performances. In this case, the investigations should unveil as maximum as possible the layers of meaning. In other words, by drowning in the communicative process. Bakhtin (2010) and Volóchinov (2017) may help us in this conversation. These authors 
were members of the Circle of Bakhtin and provided a socio-ideological/ dialogical point of view of the language.

To follow the Circle's perspective, we need to understand the philosophic basement that surrounds all the ideas of it. The ethical act, according to Bakhtin (2010), means the decision made by the individual, or self-body, connecting two axes, world, and life. The axis of the world is related to the content and is relatively stabilized, while the axis of life means the existence; what is lived and never repeated. By their acts, individuals are constantly changing the world and its meanings based on the situations that they experience. Since these two axes meet at the act, Bakhtin (2010) asserts that we have a double responsibility: by the choices, the moral responsibility, and by changes in the content, the special responsibility. About this, Sobral (2008, p. 224) affirms that "all acts have three elements in common: the actor who acts, the place and the time that the person acts".

The main idea is that the one who is acting lives a decision process and stands on contents already produced by others. Thus, decision means performance of the act and its supported by two plans, the collective and the individual. However, how the authors describe and study this decision? Based on the enunciation, the language in use. Bakhtin (2016) argues that language is the link between all human activities, since it permeates, and is permeated by all of them. The concept of language to Bakhtin's Circle is grounded in the relation between "Me" and "Other", being the alterity preeminent, once it is rooted in the multiple voices evoked by an individual when enunciates. Related to these voices is the collectivity, the other, who came before and for whom the individual will provide new meanings by the enunciation.

Communication or discursive interaction is understood as a social event, triggered by enunciative exchange, by the interrelationship of a speaker with a listener, through enunciation uttered (VOLÓCHINOV, 2017). However, the basis of interaction is the process of alterity, which, as already discussed, implies ' $m e$ ' and 'other' relationship through the ethical act. Connecting these ideas to the ergological approach, we can assume that workers act in the activity, which means assume that they found their decisions on the context, as well as they are building it by their choices. In this sense, Volóchinov (2013, p. 141) emphasizes that "language is the product of collective human activity and reflects in all its elements both the economic and sociopolitical organization of the society that generated it".

Volóchinov (2017) points out that the chain of ideological creation and understanding is unique and uninterrupted, 
because it is through the signs that the individuals act responsively and responsibly. The signic movement of reflection and refraction is determined by the ideological communication, materialized by enunciation. In this context, the Circle emphasizes that

[...] the signic character and the fact that communication is absolutely decisive are clearly and fully expressed in language. The word is ideological phenomenon par excellence (VOLÓCHINOV, 2017, p. 98).

Volóchinov also emphasizes that the word is a medium privileged of the social communication, because it shows the tensions that happen in the collective space. "The word is neutral in relation to any specific ideological function. It can take on any ideological function". (VOLÓCHINOV, 2017, p. 98).

When a person chose to work at a coworking space, different reasons supports his/her choice. The interpretation of the act reveals these reasons in a context founded by the alterity relation. In reality, the use that the coworkers make from the coworking will define what coworking is with more consistency than an institutional statement or advertising, or even the philosophy of the movement (JONES et al., 2009). Coworking means the "self-body use by the other" because each organization has its way to exist even if grounded in a concept or part of it (movement, space, activity).
The coworker, in its turn, chose the organization for some reason and made decisions in the way he/she lives the work in this context, what we mean by the "self-body use by itself". The coworker will receive a range of norms to follow, from the coworking and actors with he/ she will be interacting. However, his/her decision in that context will define how the norms of that community will be changed/maintained. Considering these remarks, we'll proceed to the dialogue between the three referred approaches.

\section{Backing to reality, how could this work?}

The previous sections were devoted to present the main ideas of each of our three perspectives in dialogue. At this point, we believe the reader already has the base to understand our assumptions and we can proceed to our goal with this research. As mentioned before, we attempt to contribute with the $\mathrm{CCO}$ perspective following its premises and attending to the invitation of Cooren et al. (2011, p. 1154):

[...] as should be clear from these six premises, no specific methodology is privileged. [...] What matters is that these studies remain grounded in action or, more precisely, in communication (as the central social practice).

Considering this note, although the contributions from the theoretical wealth 
already triggered by the authors of the $\mathrm{CCO}$, we believe that the points of view of Ergology and Bakhtin's Circle allow the identification of diverse interacting elements, based on the alterity process, whose emphasis is on the positioning of the actors in situation.

The study of communicational events is the first premise pointed by Cooren et al. (2011). The philosophic perspective from Bakhtin concerning the ethical act help us to visualize how our decisions are made based on alterity relations and our perception about it. We receive the messages by several manifestations of language: words, gestures, all that compose the enunciation, what includes values, behavior, etc. According to the Bakhtin's Circle (VOLÓCHINOV, 2017; BAKHTIN, 2010, 2016), when we enunciate, we select words considering effects in the other, but that selection is just possible because we are immersed in the world full of others voices. This cycle explains the dialogism as a process nurtured by the interactions of the ethical act. In this way, we see that the activity of work is also supported by that act, what highlights how workers are creating and reinforcing norms.

Norms are always discursive manifestations, and as Schwartz \& Durrive (2003) demonstrate, the activity of work means an effort of conciliation among enunciations directly connected to it and others coming from different levels of meaning. The macro-level is defined by social standards and we rarely identify an individual as its creator. The agency, at this level, is usually attributed to a collective and this is the main feature. About coworking, for example, we can identify the macro-level based on articles in journals, blog texts, and other all kinds of publication, that tries to establish a definition recognizable for the most part of people. When the coworking's owners chose how to announce and invite coworkers to work at their organization, we also are talking about this macro-level of communication, which events are produced intending to orientate actions at the micro-level.

All actions at the micro-level of communication represent the choices made by individuals and, as such, refer to the ethical act in activity. At this level, we can understand the meanings that support worker's choices, as well as how his/her decisions are reflecting and refracting the environment. By diving in activity, workers, researchers, and managers can develop political decisions considering peculiarities that come from the imbrication of the norms of the macro and meso-level over a situation, specific and irreplaceable, that's the stage to real articulations. The meso-level reveals how the connection between norms and renormalizations happens since contradictions and rearrangements are its base. Summarizing, we can imagine 
a timeline based on the activity of work. The closest communicational events are in adherence and reveal individuals interventions at reality. The farther discursive manifestations are in nonadherence because they are defined by hypothetical situations.

The second premise pointed by Cooren et al. (2011) concerns a broad view about communication, including multiples bases of language produced by human and nonhuman agents. Considering the three levels of communicative events in organizations, we include in our analyses the verbal manifestations coming from interviews, observations, texts shared in websites, all kinds of norms, and the verb-visual expressions as advertising, layout of the space, colors, devices, and machines. The set of these communicational events aims to influence the understanding of situations, pushing the actors' choices. As a permanent movement, dialogically constituted, all of them influence each other. An ordinary example: when the owners of a coworking chose the furniture to compose the environment, they base their choice in some style that they believe as the best. It's important to remember that choice is an utterance. However, when coworkers come, they bring their computers and resources, changing that initial enunciation.

As we can presuppose at this point in the text, the third premise of $\mathrm{CCO}$
(COOREN et al., 2011) is pervaded by the ethical act (BAKHTIN, 2010) in activity (SCHWARTZ; DURRIVE, 2003). If we accept that all situations are unique, consequently we admit that individuals interacting with others, human or nonhuman, are making decisions, which means enunciating, communicating. The chain produced by these events determines what reality means to a community, condensing several individual perspectives. Bakhtin (2016) defines three peculiarities of the enunciation, which clarifies this recognition of the co-construction and co-orientation nature of communication. The first, the expressive element, involves the emotive-volitional tone, and the evaluation permeated by the enunciative choices. The second one indicates the delimitation of the utterance through the alternation of actors. The active positions of the speaker and the listener alternate when they are in the communicative exchange.

The last peculiarity of enunciation implies both CCO premises, the third and the fourth. Each enunciation responds to another while anticipating and boosting its response. From the conclusion of the utterance given, one other emerges. This chain of utterances rooted in the context represents the alternation of actors or the relation of alterity. The impossibility to determine where the enunciation starts or ends contributes to 
the understanding that the agency is an open question. For example, considering the macro-level of communication in nonadherence discourses, the authorship is promulgated to a third being, that synthesizes the work of different professionals, at different times. The agency, here, is attributed to the organization, even if in the enunciative creation, one, or more individuals (selfbody) were involved.

The unit of analysis to the CCO perspective is the communicational events, which in the case of our purpose congregate different discourses, in adherence and nonadherence with the activity of workers, especially in the context of coworking. We argue that both are interrelated, running actively in the construction of reality. Finally, the sixth premise listed by Cooren et al. (2011) implies an equivalence between organization and organizing. With the update raised by Schoeneborn, Kuhn, and Kärreman (2018), we'll add organizationality as the third orientation linked to the CCO. By this, we mean the conjunction between the entity (organization), the process (organization) and levels of characterization (organization) clarified by communication.

In this case, by one hand, we recognize that the adoption of the ergological point of view, which deals with the dynamics between norms and renormalizations. On the other hand, we learn with
Bakhtin's Circle perspective to understand the enunciation as the nurturing point of interactions, based on social and ideological elements. By the dialogue presented, we conceive the communication with each of the mentioned orientations, organization, organizing and organizationality, and an imbrication between them, which supports the notion of coworking, for now, theoretically elaborated. Dealing with coworking implies recognizing the complexity of an ongoing phenomenon, which evidences the interdependence between notions of work and organization, being grounded three-dimensionally, like space, activity, and movement. To advance in our objectives with this research, we'll present some definitions that support our concept. However, at this text in the scope of the nonadherence.

Considering the relation between norms and renormalizations, limitations and initiatives, we take the platform Coworking Wiki as an example. We can assume that their creators had the purpose to limit a phenomenon that was arising, deliberating what was important for them in such a definition. However, with the diffusion of the idea, we can perceive that several are the appropriations, while it becomes quite difficult to establish a common understanding, especially transcending the visible of the activity. Often, the discourses imply the space, the operation 
and the professional profile of the public (segments and legal constitutions). In short, as a social movement, alive and recent, it reaches the limit of norms, of the renormalizations already incorporated, made anonymous and antecedents. From them, it appears that there is a debate going on.

We return to the definition of coworking proposed by Jones et al. (2009), for whom it is a word that serves to express an activity (verb), a movement (proper name) or a space (adjective). According to the evaluative emphasis adopted by the speaker, the layers of sense related to ideological definitions will variate, although it conserve some of it common aspects, especially in the context of the organization of work. However, when we say 'coworking space', we are associating our understanding with an ideological formation of sharing, especially of resources. In contrast, the expression 'coworking activity' is linked to the ideological formation of collaboration, in a relational sense. The different ideological functions assumed by the word coworking show the scope of tensions, the multiple voices that find shelter on it. They also show that, in contemporary times, the volume of recognizable ideological formations makes their study more complex; the study of social relations from the language manifestations.

Therefore, considering the discussion presented in this article, coworking is understood as an organizational arrangement constituted by communication practices linked to the activity of work from individuals engaged in the purpose of working collaboratively to produce knowledge. The peculiarity of work in coworking is the gathering diversity of professionals and areas of operation. However, cohabiting in this sort of space is a choice that often does not entail selection procedures. People choose to be there, they join the spaces according to their will, they organize themselves according to perspectives that they believe will be shared. We use the term 'arrangement' that is connected with construction, something in constant mobilization, even if it has an initial purpose - where somebody wants to arrive. By using 'organizational' as an adjective related to the arrangement, this aspect of the junction is confirmed around some common axis: collaboration.

After the discussion, we can summarize the dialogue proposed assuming that the ethical act is the link between the self-body and the environment. The organizational analysis is challenged to consider this dimension to its constitution, conceiving and guaranteeing human dignity, in a more complex and democratic way. In the specific scope of this investigation, therefore, if the coworker dedicates his/her look to the coworking, privileging the space and its resources or the service provided, for example, this 
act finds echo in the manifestations from the environment, in the macro, meso and micro organizational levels as in the broader social horizon, where that worker is inserted. It is justified, then, to understand how the interactional dynamics are base on the organizational constitution in coworking.

\section{The final considerations}

The environment shared between human beings and technology is not a huge innovation, but all dimensions of human life have been changing as a result of the time relation to produce and to adapt to technology. The way we look at these changes implies the clues that we take from the context to understand and participate in its edification. As beings dependents of culture and collective definitions, we are always searching for possibilities to shape the closest environment according to our wishes and conceptions. However, our interpretation of the facts that faces us, always can be modified according to the situations. All this complex web from the predefined to the real situations is moving and, like this, is anchoring organizations. This research allows us to visualize this volatile network, recognizing all levels acting communicatively to structure organizations.

At the macro-level, the discursive manifestations are projected and elaborated through the conjunction of perspectives coming from a group of actors, in the form of constituted savoirs and norms. It refers to the communicational events, that sometimes conflict with the other dimensions, because it is a knowledge created in association with other social values of the global reality, which ignores (partially) the local and internal translation of the organization. The meso-level implies visibly a hybrid space related to a normative constitution. It brings together what is antecedent in the productive processes in an organization, as well as what is renormalized from the activity of the workers. In this case, at this level the imbrication between savoirs constituted and invested can be recognized. At the micro-level, we recognize the agency of the self-body implying the culture of the organization while his/her behavior is also modified.

Our research proposes a dialogue between ergology and the socio-ideological perspective of language as a possibility to understand how organizations are constituted, but also how they influence the daily activities experienced by individuals. Work is considered the base of all organizations, besides its productive aspects, but as a human activity related to the environment, that defines the way the workers understand and shape their social relations. By this choice, our first contribution is to highlight how to reveal people's perspective about the changes 
in a context that usually put the lights in technology. In our perspective, this is primordial to understand and transform the future of work in a democratic way, preparing and forming workers to it. Aware of the complexity that bonds this topic, we opt to see the coworking phenomenon differently, considering its bases as a new way to work.

The CCO is a recent theoretical construct that challenges us to explore the communicational dimension based on all sorts of interactional events. As mentioned in the previous sections, it deals with a pluridisciplinar framework. This characteristic encourages us to contribute with it respecting the six premises, however bringing new lens to emphasize the communicative constitution of the organizations, its process of organizing and its features, which supports the appreciation of coworking by this angle. We believe that this kind of organizational arrangement allows us to observe the complexity around the imbrication between work and organization, especially taking into account the new jobs and its reengineering. More than ever, if we are looking for alternatives anchored in democracy and ethics, we need to change the lens to investigate the transposition among the communicative levels that reveals the layers of meaning.

Despite these contributions, the proposal presented in this paper requires refinement, especially to frame all the possible connections. We face this as a challenge that pushes us to continue our research, designing future projects. Furthermore, we believe that aggregating discourses from the micro and meso-levels we can visualize how the concept of coworking, shaped here, is confronted and renormalized by the situations that coworkers experience in their work. The diversity inherent to its base can be an inspiration to improve the alterity relation respecting and growing from the differences. However, to achieve this goal, we need to understand people's activity and encourage them to interpret their ethical acts, recognizing how they reflect and refract the multiple ideologies that surround the social web. Which is the path to that? Communicatively constituted.

\section{Ergologia e o ponto de vista socio-ideológico da comunicação: bases para repensar a constituição das organizações}

\section{Resumo}

A mundialização e o desenvolvimento tecnológico são vetores que impulsionam mudanças nos modos de interação entre indivíduos, logo implicam na percepção e no engajamento a construção da realidade que os cerca. $\mathrm{O}$ contexto organizacional não é isento desses processos e passa a ser evi- 
dente diante de diferentes iniciativas dos trabalhadores, como a criação de ambientes laborais compartilhados, colaborativos e não hierárquicos. Esses apontamentos convergem para a problematização: como as organizações passam a ser constituídas sob o enfoque comunicacional? $\mathrm{O}$ argumento que orienta a busca de resposta a esse questionamento perpassa a imbricação entre as perspectivas ergológica e do Círculo de Bakhtin e encontra no coworking sua base para reflexão. $\mathrm{O}$ artigo se constitui de quatro blocos, a começar pela inter-relação entre as concepções de atividade laboral e de interação verbal, como suporte para o entendimento do processo comunicacional constitutivo das organizações. Por fim, vislumbra-se o coworking como horizonte para tal proposição investigativa.

Palavras-chave: Ergologia. Perspectiva Socioideológica. CCO. Coworking.

\section{Notas}

1 "It was to avoid inserting this re-focusing effort into the overly codified problems of the 'subject', of 'subjectivity' (which involved the risk of neutralizing the dimension of a search for life in us) that we prefer to use the voluntarily obscure term 'self'. (Schwartz, 2014, p. 261). An enigmatic concept to refer to a complex and paradoxical being, like the human.

2 We chose to maintain the original term in the French language (savoir) because the meaning of the word "knowledge" is closer to "connaissance" (French), referring to something already agreed by society. The word savoir is related to meaning construction in daily life, which means more flexibility.

3 In french : L'usage de soi par l'autre.

4 In french: L'usage de soi pour soi-même.

\section{References}

BAKHTIN, Mikhail. Para uma Filosofia do Ato. 2. Ed., São Carlos: Pedro \& João Editores, 2010.

BAKHTIN, Mikhail. Os gêneros do discurso. Tradução: Paulo Bezerra. RJ: Editora 34, 2016.

BLAGOEV, Blagoy; COSTAS, Jana; KÄRREMAN, Dan. 'We Are All Herd Animals': Community and Organizationality in Coworking Spaces. Organization, 2019. Disponível em: https://doi.org/10.1177/1350508418821008. Acesso em: 08 jun. 2019.

COOREN, François; et al. Communication, Organizing and Organization: An Overview and Introduction to the Special Issue. Organization Studies, v. 32, n. 9, p. 1149-1170, 2011.

CUCHE, Denys. A Noção de Cultura nas Ciências Sociais. Bauru: EDUSC, 1999.

DEETZ, Stanley. Comunicação Organizacional: fundamentos e desafios. In: MARCHIORI, Marlene (org.). Comunicação e Organização: reflexões, processos e práticas. São Caetano do Sul, SP: Difusão, p. 83 - 101, 2010.

DOBUSCH, Leonhard; SCHOENEBORN, Dennis. Fluidity, Identity, and Organizationality: the Communicative Constitution of Anonymous. Journal of Management Studies, v. 52, n. 8, p. 1005-1035, 2015.

DURRIVE, Louis. L'expérience des normes. Comprendre l'activité humaine avec la démarche ergologique. Toulouse: Octares éditions, 2015.

GEERTZ, Clifford. A Interpretação das Culturas. Rio de Janeiro: LTC, 2008.

HAUBRICH, Gislene Feiten. Coworking is not a place, it's the people: um olhar comunicacional à produção de sabers no Brasil e na França. 2019. 269f. Tese (Doutorado) - Programa de Pós-graduação em Processos 
e Manifestações Culturais, Universidade Feevale. Novo Hamburgo. 2019.

JONES, Drew. et al. I'm Outta Here!: How Coworking is Making the Office Obsolete. Texas: NotanMBA Press, 2009.

McPHEE, Robert D.; ZAUG, Pamela. The Communicative Constitution of Organizations: a framework for explanation. In: PUTNAM, Linda; NICOTERA, Anne Maydan (org.). Building Theories of Organization: the constitutive role of communication. New York: Taylor \& Francis, 2009. p. 21-47.

MANYIKA, James. (McKinsey Global Institute). What is the future of work? 2017. Disponível em: https://www.mckinsey.com/ featured-insights/future-of-work/what-is-the-future-of-work. Acesso em: 27 jun. 2019.

PUTNAM, Linda; NICOTERA, Anne Maydan; MCPHEE, Robert D. Introduction: communication constitutes organization. In: PUTNAM, Linda; NICOTERA, Anne Maydan (org.). Building Theories of Organization: the constitutive role of communication. New York: Taylor \& Francis, 2009. p. 1-19.

SCHOENEBORN, Dennis. Organization as Communication: A Luhmannian Perspective. Management Communication Quarterly, v. 25, n.4, p. 663-689, 2011. Disponível em: https://papers.ssrn.com/sol3/papers. cfm?abstract_id=2186532. Acesso em: 09 de jul. 2019.

SCHOENEBORN, Dennis; KUHN, Timothy R., KÄRREMAN, Dan. The Communicative Constitution of Organization, Organizing, and Organizationality. Organization Studies, v.40, n.4, 2019. Disponível em: https://doi. org/10.1177/0170840618782284. Acesso em: 27 jun. 2019.

SCHWARTZ, Jeff ; et al. (Deloitte Insights). What is the future of work? 2019. Disponível em: https://www2.deloitte.com/insights/us/ en/focus/technology-and-the-future-of-work/ redefining-work-workforces-workplaces. html. Acesso em: 27 jun. 2019.
SCHWARTZ, Yves. Travail et Ergologie. In: SCHWARTZ, Yves. (org.). Reconnaissances du Travail: pour une approche ergologique. Vendôme: Presses Universitaire de France, p. 1-37, 1998.

SCHWARTZ, Yves ; DURRIVE, Louis (org.). Travail et ergologie : entretiens sur l'activité humaine, Toulouse, Octarès Éditions, 2003.

SCHWARTZ, Yves; DURRIVE, Louis. (Org.). L'activité en dialogues. Entretiens sur l'activité humaine (II) suivi de : Manifeste pour un ergo-engagement, 2009.

SOBRAL, Adail. O Ato "Responsível”, ou Ato Ético, em Bakhtin, e a Centralidade do Agente. SIGNUM, v. 11, n.1, p. 219-235, jul., 2008.

TAYLOR, James R. Is There a 'Canadian' Approach to the Study of Organizational Communication? Canadian Journal of Communication, v. 25, n.1, 2000. Disponível em: https:/cjc-online.ca/index.php/journal/article/view/1147/1066. Acesso em: 09 jul. 2019.

VIDAILLET, Bénédicte; BOUSALHAM, Youcef. Coworking spaces as places where economic diversity can be articulated: Towards a theory of syntopia. Organization, 2018. Disponível em: https://doi. org/10.1177/1350508418794003. Acesso em 08 jun. 2019.

VOLÓCHINOV, Valentin. A construção da enunciação e outros ensaios. Tradução de: João Vanderley Geraldi e Valdemir Miotello. São Carlos: Pedro \& João Editores, 2013.

VOLÓCHINOV, Valentin. Marxismo e Filosofia da Linguagem. Tradução de Sheila Grillo e Ekaterina V. Américo. São Paulo: Editora 34, 2017.

WOLTON, Dominique. Informar não é comunicar. Porto Alegre: Sulina, 2011. 